\title{
Growth and egg production of female Calanus finmarchicus: an individual-based physiological model and experimental validation
}

\author{
François Carlotti ${ }^{1, *}$, Hans-Jürgen Hirche ${ }^{2}$ \\ ${ }^{1}$ Université P. et M. Curie (Paris VI), C.N.R.S.- I.N.S.U., URA 2077, Station Zoologique, BP 28, F-06230 Villeíranche-sur-Mer, France \\ ${ }^{2}$ Alfred Wegener Institute for Polar and Marine Research, Kolumbusstr. 1, D-27656 Bremerhaven, Germany
}

\begin{abstract}
A detalled individual-based model of egg production of Calanus finmarchicus is proposed. Female growth and egg production are represented by 8 state variables (gut content, nutrient pool, structural body, oll sac, and 4 stages of oocyte maturation) which are regulated by physiological processes. Clutch size is set constant under continuous food conditions, but the spawning interval changes with food availability and temperature depending on the rate of oocyte maturation. Smaller clutches can occur when eggs are released under bad external conditions. Thus changing conditions can produce different clutch size distributions. For model validation, egg production experiments were conducted under different constant and fluctuating food concentrations and compared with model simulations. In the experiments, egg production was strongly affected by food fluctuation. In experiments with alternating feeding and starvation cycles integrated egg production was affected by mean food concentration during the experiment rather than by the frequency of the cycles. The model reproduces correctly the egg production rates and final body carbon of females kept in the different food regimes. It provides a dynamical explanation of physiological responses of the individual under shortterm food variation. When food becomes unavailable, the most advanced oocytes are released and egg production continues until the nutrient pool decreases below a minimal critical value. Thereafter, no eggs are laid. When food reappears, somatic growth resumes until structural body weight is restored, then oogenesis is fuelled. Experımental results were simulated correctly without using matter from the lipid pool.
\end{abstract}

KEY WORDS: Calanus finmarchicus Egg production Physiological model · Growth

\section{INTRODUCTION}

The copepod Calanus finmarchicus is a key species in the pelagic system of the northern North Atlantic, where it is an important link between phytoplankton and fish populations that feed on Calanus spp. eggs and juveniles during the early larval stages (Runge 1988, Ohman \& Runge 1994). Due to C. finmarchicus reproductive strategy, its breeding is much more episodic than that of smaller copepod species, for whom it is more continuous (Frost 1985, Marshall 1949). This high variability in recruitment has a strong bearing on higher trophic levels in Calanus-dominated

-E-mail: carlott@ecrv.obs-vlfr.fr systems, but also on the phytoplankton through the changing grazing pressure (Carlotti \& Radach 1996). The reproductive biology of $C$. finmarchicus is therefore a key process both for the dynamics of Calanus populations and the ecosystem in which they develop.

The reproductive biology of Calanus finmarchicus has been studied extensively in the laboratory under different food and temperature conditions (Runge 1985, Hirche et al. 1997) and in the field in different regions (e.g. Marshall \& Orr 1955, Runge 1985, Hirche 1990, Diel \& Tande 1992, Ohman \& Runge 1994) and has recently been reviewed by Hirche (1996). However, these studies have not integrated female reproductive physiology with growth and general metabolism.

Sciandra et al. (1990) presented a physiological model of the egg production of Centropages typicus 
which was consistent with experimental data of egg production in constant and varying food conditions. They showed that there is not a simple relationship between food availability and egg production and that the pool of metabolic reserves and the processes of oogenesis play an important role in the dynamics of egg production. Their model was designed to simulate results of experiments under conditions of constant temperature and fluctuating food (Nival et al. 1990).

However, there are 2 main reasons why the model of Sciandra et al. (1990) cannot be coupled with a population dynamics model or be used to simulate field situations. Firstly, in Sciandra et al.'s (1990) model the organism is only represented by the gut, the gonads and the metabolic reserves. The structural weight, which represents hemolymph, cuticule and muscles, is missing. Considerable changes of weight of individual copepods, mainly related to temperature and feeding conditions, have been reported both for small copepods such as Centropages spp. (Razouls \& Guiness 1973, Klein Breteler \& Gonzalez 1982), and for large species such as Calanus spp. (Carlotti et al. 1993). Several authors have shown that the egg production of female copepods is related to their weight or length (e.g. Corkett \& McLaren 1969, Smith \& Lane 1985, Hirche 1990). There are marked interspecific differences in the response to starvation. In contrast to Centropages spp. females, which survive starvation only a few days ( 3 to $8 \mathrm{~d}_{i}$ authors' pers. obs.), females of Calanus spp. can survive long periods of unfavourable conditions and resume spawning thereafter (Runge 1984, Hirche 1990, Hirche \& Kattner 1993). To correctly represent the reproduction process in models of population dynamics, which couple growth and development (e.g. Carlotti \& Radach 1996), a realistic model of egg production should include female growth and egg production. Secondly, the dynamics of the flux of matter during egg formation should be represented. Sciandra et al. (1990, their Fig. 1) consider 1 compartment of metabolic reserves and 2 compartments representing 2 steps of egg formation, called oocyte1 and oocyte2. They proposed a linear flux of matter between these 3 compartments. In fluctuating food conditions, their model predicts the observed lag-time in the response of egg production rates. These simulated lag-times, however, result more from the mathematical properties of the transfer function used to represent the flux between successive compartments, the Hill function acts as a buffer to lessen the use of the metabolic reserves, than from the representation of the physiological properties of the copepod.

Knowledge of egg formation is greatly increasing (Blades-Eckelbarger \& Youngbluth 1984,
Razouls et al. 1986, 1987, Ianora et al. 1989). Niehoff \& Hirche (1996) have recently studied in detail the oogenesis and spawning cycle of Calanus finmarchicus, and distinguished 1 type of oogonia and 4 types of oocytes at different stages of maturation. The representation of a completely linear flux of matter from one oocyte compartment to the next one, as in Sciandra et al.'s (1990) model, does not agree with the experimental results for these processes. Instead, the model should represent a transfer of oocytes between 'maturity' compartments in the gonad, and a flux of nutritive matter from the nutrient pool of the hemolymph towards the oocytes in each maturity compartment. After growing from these nutrients and reaching a certain maturation state, oocytes should be transferred to the following maturity compartment until ready to be spawned.

The purpose of this study is to present a complete model of the reproduction of female Calanus finmarchicus including updated knowledge on the physiological processes involved in its development from the newly moulted adult to maturity. To validate such a model, experiments of egg production were conducted under both constant food and starvation conditions as well as in feeding-starvation cycles of different frequencies.

\section{MODEL CONCEPTUALISATION}

We consider that somatic growth and egg production of female Calanus can be represented basically with 8 state variables (Fig. 1): the gut content, the nutrient pool, the structural body, the oil sac, and 4 compartments containing different stages of oocyte maturation

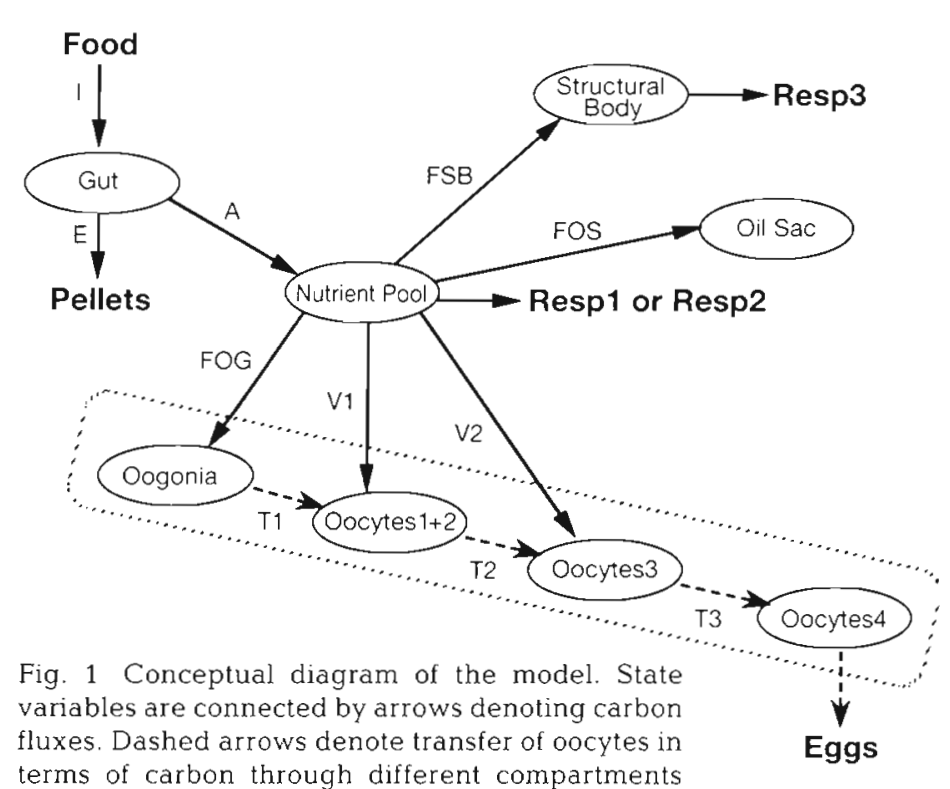

terms of carbon through different compartments of maturity. Symbols are explained in Table 1 
as described by Niehoff \& Hirche (1996). Food and temperature, which are considered as the most important external parameters for the survival of Calanus (Vidal 1980), are used as forcing parameters

The differential equations and the functions representing these processes are listed in Table 1 and coefficient values are presented in Table 2. As a unit of mass, $\mu \mathrm{g} \mathrm{C}$ was chosen.

The ingestion function of Calanus finmarchicus takes into account the effect of food concentration following a Michaelis-Menten function; the effect of temperature following an exponential function; and the effect of body weight following an allometric function. Values of the threshold food concentration $\left(P_{2}\right)$ and halfsaturation concentration $\left(\mathrm{P}_{3}\right)$ were taken from Gamble
(1978; see also Steele 1974). The coefficient of the allometric relationship between ingestion and weight $\left(P_{5}\right)$ is from Paffenhöfer (1971). Using a maximum intrinsic ingestion coefficient $\left(\mathrm{P}_{1}\right)$ of $0.762 \mathrm{~d}^{-1}$ at $0^{\circ} \mathrm{C}$ and a temperature increase of ingestion $\left(\mathrm{P}_{4}\right)$ equal to 1.077 , which corresponds to a $Q_{10}$ of 2.1 (Gamble 1978), we obtained for a female of $100 \mu \mathrm{g} \mathrm{C}$ maximum feeding rates of $40.2 \mu \mathrm{g} \mathrm{C}$ ind. ${ }^{-1} \mathrm{~d}^{-1}$ at $10^{\circ} \mathrm{C}$ and $19.14 \mu \mathrm{g} \mathrm{C}$ ind. ${ }^{-1} \mathrm{~d}^{-1}$ at $0^{\circ} \mathrm{C}$. These ingestion rates are similar to experimental data obtained by Gamble (1978) and Tande \& Bămstedt (1985) at comparable temperatures. The gut transit time is ca $45 \mathrm{~min}$ for $\mathrm{C}$. finmarchicus (Hansen et al. 1990), which is equivalent to 32 gut turnovers per day $\left(P_{6}\right)$. We assume that $3 / 4$ of the ingested matter is assimilated and $1 / 4$ is egested $\left(\mathrm{P}_{7}\right)$.

Table 1 Differential equations and mathematical functions of model processes. Symbols of state variables are in bold. Rates of processes in conditions not stated explicitly are equal to zero. Temp: temperature. $P_{1}$ to $P_{2 g}$ : biological parameters (see Table 2)

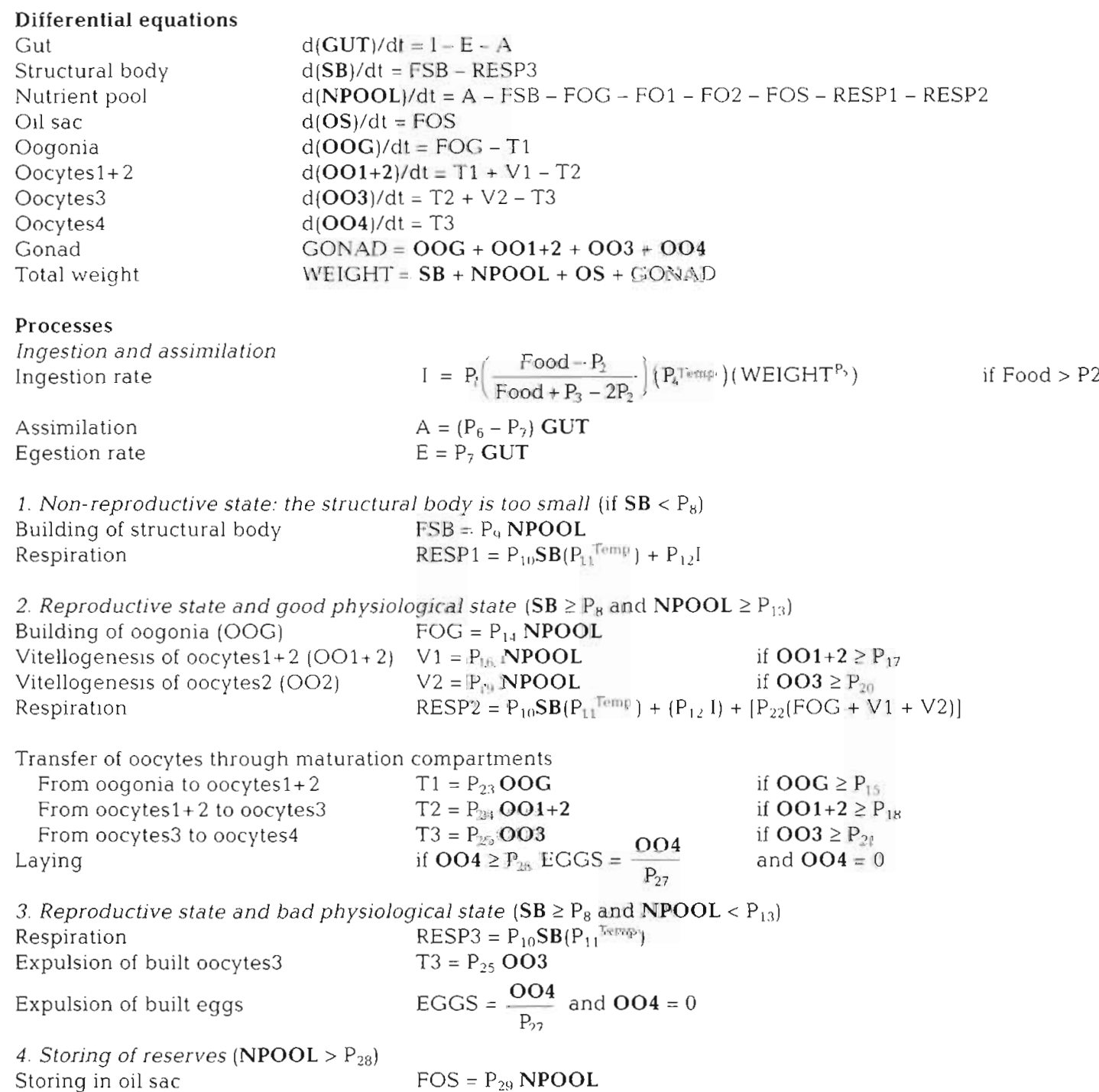

\section{Processes}

Ingestion and assimilation Ingestion rate

$$
\begin{aligned}
& I=P_{1}\left(\frac{\text { Food }-P_{2}}{\text { Food }+P_{3}-2 P_{2}}\right)\left(P_{4}^{\text {Temp }}\right)\left(\text { WEIGHT }^{P_{3}}\right) \\
& A=\left(P_{6}-P_{7}\right) \text { GUT } \\
& E=P_{7} \text { GUT }
\end{aligned}
$$$$
\text { if Food }>\text { P2 }
$$

Assimilation

Egestion rate

1. Non-reproductive state: the structural body is too small (if $\mathrm{SB}<\mathrm{P}_{8}$ )

Building of structural body $\quad F S B=\mathrm{P}_{4}$ NPOOL

Respiration

RESP1 $=P_{11} S B\left(P_{1}^{\text {Temp }}\right)+P_{12} I$

2. Reproductive state and good physiological state $\left(\mathrm{SB} \geq \mathrm{P}_{\mathrm{H}}\right.$ and $\left.\mathrm{NPOOL} \geq \mathrm{P}_{13}\right)$

Building of oogonia (OOG) $\mathrm{FOG}=\mathrm{P}_{14} \mathrm{NPOOL}$

Vitellogenesis of oocytes $1+2(0 O 1+2) \quad V 1=\mathrm{P}_{16}$ NPOOL

Vitellogenesis of oocytes $(\mathrm{OO} 2) \quad \mathrm{V} 2=\mathrm{P}_{19}$ NPOOL

if $\mathrm{OO} 1+2 \geq \mathrm{P}_{17}$

Respiration

$\operatorname{RESP} 2=\mathrm{P}_{10} \mathrm{SB}\left(\mathrm{P}_{11}{ }^{\text {Temp }}\right)+\left(\mathrm{P}_{12} \mathrm{l}\right)+\left[\mathrm{P}_{22}(\mathrm{FOG}+\mathrm{V} 1+\mathrm{V} 2)\right]$

Transfer of oocytes through maturation compartments

From oogonia to oocytes $1+2 \quad \mathrm{~T} 1=\mathrm{P}, \mathrm{OOG}$

From oocytes $1+2$ to oocytes $3 \quad \mathrm{~T} 2=\mathrm{P}_{24}$ OO1 +2

From oocytes 3 to oocytes $4 \quad \mathrm{~T} 3=\mathrm{P}_{25}$ OO3

Laying

$$
\begin{array}{ll}
\mathrm{T} 3=\mathrm{P}_{25} \mathrm{OO} 3 & \text { if } \mathrm{OO} 3 \geq \mathrm{P}_{21}
\end{array}
$$

if $\mathrm{OOG} \geq \mathrm{P}_{15}$

if $0 O 1+2 \geq P_{18}$

and $\mathrm{OO} 4=0$

3. Reproductive state and bad physiological state $\left(\mathrm{SB} \geq \mathrm{P}_{8}\right.$ and NPOOL $\left.<\mathrm{P}_{1,3}\right)$

Respiration

Expulsion of built oocytes 3

RESP3 $=\mathrm{P}_{10} \mathrm{SB}\left(\mathrm{P}_{11}{ }^{\text {Temp }}\right)$

Expulsion of built eggs

$\mathrm{T} 3=\mathrm{P}_{25} \mathrm{OO} 3$

4. Storing of reserves $\left(\mathrm{NPOOL}>\mathrm{P}_{28}\right.$ )

Storing in oil sac

$\mathrm{EGGS}=\frac{\mathrm{OO4}}{\mathrm{P}_{37}}$ and $\mathrm{OO4}=0$

FOS $=\mathrm{P}_{24}$ NPOOL 
Table 2. Parameter values used in the model. wd: dimensionless

\begin{tabular}{|c|c|c|}
\hline Parameter & Value & Unit \\
\hline$P_{1}$ Maximal specific ingestion rate at $0^{\circ} \mathrm{C}$ & 0.762 & $d^{-1}$ \\
\hline $\mathrm{P}_{2}$ Food threshold for ingestion & 50 & $\mu g \mathrm{Cl}^{-1}$ \\
\hline \multicolumn{3}{|l|}{$P_{3}$ Half-saturation concentration of } \\
\hline Michaelis-Menten function & 75 & $\mu \mathrm{Cl}^{-1}$ \\
\hline $\mathrm{P}_{4}$ Tenth root of $Q_{10}$ coefficient of ingestion rate & 1.077 & wd \\
\hline $\mathrm{P}_{5}$ Exponent of the allometric relation to weight & 0.7 & $w d$ \\
\hline$P_{6}$ Rate of gut evacuation & 32 & $d^{-1}$ \\
\hline $\mathrm{P}_{7}$ Egestion rate & 8 & $d^{-1}$ \\
\hline$P_{8}$ Critical weight for egg building & 80 & $\mu g \mathrm{C}$ \\
\hline \multicolumn{3}{|l|}{$P_{9}$ Rate of nutrient flux from body fluid to the } \\
\hline $\mathrm{P}_{10}$ Respiration rate at $0^{\circ} \mathrm{C}$ & 0.01176 & $\mathrm{~d}^{-1}$ \\
\hline$P_{11}$ Tenth root of $Q_{10}$ coefficient of respiration rate & 1.13 & wd \\
\hline $\mathrm{P}_{12}$ Proportionality between metabolic and ingestion rates & 0.27 & $d^{-1}$ \\
\hline$P_{13}$ Threshold content of nutrient pool in the body fluid & 1 & $\mu g C$ \\
\hline $\mathrm{P}_{14}$ Rate of nutrient flux from body fluid to build oogonia & 0.5 & $d^{-1}$ \\
\hline$P_{15}$ Critical mass of oogonia for transfer in oocytes $1+2$ & 2 & $\mu \mathrm{gC}$ \\
\hline$P_{16}$ Rate of nutrient flux in body fluid to feed oocytes $1+2$ & 0.25 & $d^{-1}$ \\
\hline$P_{17}$ Minimum mass of oocytes $1+2$ to induce nutrient flux & 1 & $\mu \mathrm{gg} C$ \\
\hline $\mathrm{P}_{1}$ Critical mass of oocytes $1+2$ for transfer in oocytes 3 & 5 & $\mu g C$ \\
\hline$P_{19}$ Rate of nutrient flux in body fluid to feed oocytes 3 & 0.25 & d 1 \\
\hline $\mathrm{P}_{20}$ Minimum mass of oocytes 3 to induce nutrient flux & 1. & $\mu g C$ \\
\hline $\mathrm{P}_{21}$ Critical mass of oocytes 3 for transfer in oocytes 4 & 10 & $\mu \mathrm{g} C$ \\
\hline \multicolumn{3}{|l|}{$\mathrm{P}_{22}$ Proportionality between metabolic rate and } \\
\hline nutrient flux for oocytes & 0.2 & $d^{-1}$ \\
\hline $\mathrm{P}_{23}$ Transfer rate of mature oogonia to oocytes $1+2$ & 5 & $d^{-1}$ \\
\hline $\mathrm{P}_{24}$ Transfer rate of mature oocytes $1+2$ to oocytes 3 & 5 & $d^{-1}$ \\
\hline $\mathrm{P}_{25}$ Transfer rate of mature oocytes 3 to oocytes 4 & 5 & $d^{-1}$ \\
\hline \multicolumn{3}{|l|}{$\mathrm{P}_{26}$ Critical mass of oocytes 4 which induces } \\
\hline expulsion of eggs & 12 & $\mu \mathrm{g} C$ \\
\hline $\mathrm{P}_{27}$ Egg carbon content & 0.23 & $\mu \mathrm{g} C$ \\
\hline \multicolumn{3}{|l|}{$\mathrm{P}_{28}$ Mass of nutrient in body fluid which induces } \\
\hline storing in oil sac & 30 & $\mu g C$ \\
\hline $\mathrm{P}_{29}$ Rate of nutrient flux in body fluid to oil sac & 0.5 & $\mu g \mathrm{C}$ \\
\hline
\end{tabular}

$\left(P_{10}\right)$ and $4 \% d^{-1}$ of the structural weight at 0 and $10^{\circ} \mathrm{C}$, respectively (Hirche 1987). Considering that $27 \%$ of the ingestion $\left(\mathrm{P}_{12}\right)$ is used for active metabolism, such as for swimming and assimilation, we obtain respiration rates of growing females in optimum conditions of 6 and $15 \% \mathrm{~d}^{-1}$ of the weight at 0 and $10^{\circ} \mathrm{C}$, respectively.

Mature female. When the female exceeds the critical structural weight, the flux from the nutrient pool is completely directed towards the growth of eggs and metabolic requirements. At $10^{\circ} \mathrm{C}$, this critical structural weight equals $80 \mu \mathrm{C} \quad\left(\mathrm{P}_{8}\right)$. Carlotti et al. (1993) found that the weight of Calanus finmarchicus females decreased when temperature increased with a slope of $-14.84 \mu \mathrm{g}$ dry wt per ${ }^{\circ} \mathrm{C}$. We use the same function for the relation between the critical structural weight of spawning and temperature with a siope of $5.94 \mu \mathrm{g} \mathrm{C}$ per ${ }^{\circ} \mathrm{C}$, assuming a ratio of carbon:dry weight equal to 0.4 .

The nutrient pool plays different roles in egg formation. First, it permits the female to build a package of oogonia in the ovary. When the compartment 'oogonia' reaches a mass equal to $2 \mu \mathrm{g} C\left(\mathrm{P}_{15}\right)$, the oogonia are transferred to the compartment 'oocytes $1+2$ ' $\left(\mathrm{P}_{23}\right)$, and the nutrient pool ensures the growth of

The assimilated matter fills a nutrient pool, which is the stock of nutritive matter in the hemolymph. The content of the nutrient pool can increase the structural weight, the oil sac, or the matter in the gonads depending on the physiological state of the animal (see Table 1). We present the processes of the model for 3 different physiological states: an immature, a mature and a starving female.

Immature female. As in the model of Carlotti \& Radach (1996), we consider that the female's structural body has to reach a critical weight value $\left(\mathrm{P}_{8}\right)$ before assimilated energy can be used for building eggs. Below this value, energy is mainly used for structural growth. The rate of nutrient flux $\left(\mathrm{P}_{9}\right)$ from the nutrient pool to the structural weight is assumed to be $0.5 \mathrm{~d}^{-1}$ The nutrient pool also provides the metabolic expenses, which can be divided into 2 types: the basic metabolism proportional to the structural weight and the active metabolism proportional to ingestion. The basic metabolism depends on temperature following a $Q_{10}$ equal to $3.4\left(P_{11}\right)$, which gives rates equal to 1.18 'oocytes $1+2$ ' by vitellogenesis 1 The transfer to the compartment 'oocytes3' $\left(\mathrm{P}_{24}\right)$ occurs when the total mass of 'oocytes $1+2$ ' through vitellogenesis 2 reaches a certain value $\left(P_{18}\right)$ equal to $5 \mu \mathrm{g} C$. The same process of growth and transfer occurs between the compartments 'oocytes 3 ' and 'oocytes 4 ' $\left(\mathrm{P}_{25}\right)$. The mass threshold of 'oocytes 3 ' is $10 \mu \mathrm{g} \mathrm{C}\left(\mathrm{P}_{21}\right)$. The nutrient pool ensures the maturity of 'oogonia', and the vitellogenesis of 'oocytes $1+2$ ' and 'oocytes 3 ', but not for 'oocytes4' which is a step of shell formation. The flux of nutrient for the vitellogenesis of 'oocytes $1+2$ ' and 'oocytes 3 ' (parameters $\mathrm{P}_{16}$ and $\mathrm{P}_{19}$ ) occurs only if a minimum biomass of oocytes is present (parameters $\mathrm{P}_{17}$ and $\mathrm{P}_{20}$ ).

We assume that the respiration rate is the same for immature and mature females with an additional cost of energy $\left(\mathrm{P}_{22}\right)$ related to the formation of oogonia and oocyte maturation (see Table 1). A basic hypothesis of our model is that clutch size does not vary with food, temperature or body weight and is around 50 eggs (Hirche 1990, his Fig. 5; Hirche et al. 1997, their Figs. $2 \mathrm{C} \& 5 \mathrm{C}$ ). In the model, as in nature (Marshall \& 
Orr 1955), egg-laying is a discontinuous process: all eggs are spawned when the mass of the compartment 'oocytes4' is $>12 \mu \mathrm{g} \mathrm{C}\left(\mathrm{P}_{26}\right)$. The egg carbon content $\left(\mathrm{P}_{27}\right)$ is equal to $0.23 \mu \mathrm{g} \mathrm{C}$ (Ohman \& Runge 1994). In the presented simulations, we do not suppose any decreasing egg production due to female senescence.

Starving female. During long-term starvation the nutrient pool will decline strongly. When it falls below a minimum value $\left(\mathrm{P}_{13}\right)$, here defined as $1 \mu \mathrm{g} C$, the basic metabolic requirements are ensured by the structural body itself The 'oocytes3' and 'oocytes4' present in the gonad are spawned quickly, regardless of the levels of maturity. When starvation lasts long enough, the structural weight decreases below the critical weight for egg production. When feeding conditions improve, the structural body should first be restored.

Calanus finmarchicus accumulates lipids in an oil sac. We assume that the excess of matter is stored as lipids in the oil sac $\left(\mathrm{P}_{29}\right)$ when the nutrient content in the hemolymph is above a threshold $\left(\mathrm{P}_{28}\right)$ fixed at $30 \mu \mathrm{g} \mathrm{C}$.

\section{MATERIAL AND METHODS OF EXPERIMENTS}

Female Calanus finmarchicus were collected in April 1994 in Korsfjorden, western Norway, from vertical tows from $200 \mathrm{~m}$ to the surface using a net $1 \mathrm{~m}$ in diameter and $500 \mu \mathrm{m}$ mesh size, fitted with a non-filtering $14 \mathrm{l}$ codend. Single females were sorted and placed in $250 \mathrm{ml}$ containers as described in Hirche (1990). Natural daylight illuminated the room through a window. Two sets of egg production experiments under constant and fluctuating food conditions were conducted at $10 \pm 1{ }^{\circ} \mathrm{C}$. The experimental schedule is shown in Fig. $2 \mathrm{~A}$. In the set of $11 \mathrm{~d}$ experiments (Exp1), freshly caught females were fed 25000 cells $\mathrm{ml}^{-1}$ of Rhodomonas baltica for 2 to $4 \mathrm{~d}$ according to Nejstgaard et al. (1995), who obtained optimum daily ration at $1200 \mathrm{mg}$ $\mathrm{C} \mathrm{m}^{-3}$ (taking $47.4 \pm 1.9 \mathrm{pg} \mathrm{C}$ cell ${ }^{-1}$; Berggreen et al. 1988). After this initial 2 to $4 \mathrm{~d}$ period, food was either removed completely (Exp1A), given at varying intervals (Exp1C-F), or given steadily (Exp1B). As egg production decreased rapidly at 25000 cells $\mathrm{m}^{-1}$, we used a concentration of 80000 cells ml ${ }^{-1}\left(3792 \mathrm{\mu g} \mathrm{Cl}^{-1}\right)$ for the rest of Exp1B. Four experiments were conducted with intervals of a $1 / 2 \mathrm{~d}(\operatorname{Exp} 1 \mathrm{C}), 1 \mathrm{~d}(\operatorname{Exp} 1 D), 2 \mathrm{~d}$ (Exp1E) and $3 \mathrm{~d}(\operatorname{Exp} 1 \mathrm{~F})$ starvation between high food


tion (Exp1A) females were placed in filtered sea water (0.5 $\mu \mathrm{m}$ GFC flow through filtration system). Each experiment started with 11 single females; in 3 of the experiments 1 female was lost (dead or not spawning).

The second set of experiments (Exp2) started $6 \mathrm{~d}$ after Exp1 and lasted 5.5 (Exp2C) and $6 \mathrm{~d}(\operatorname{Exp} 2 \mathrm{~B}$ and
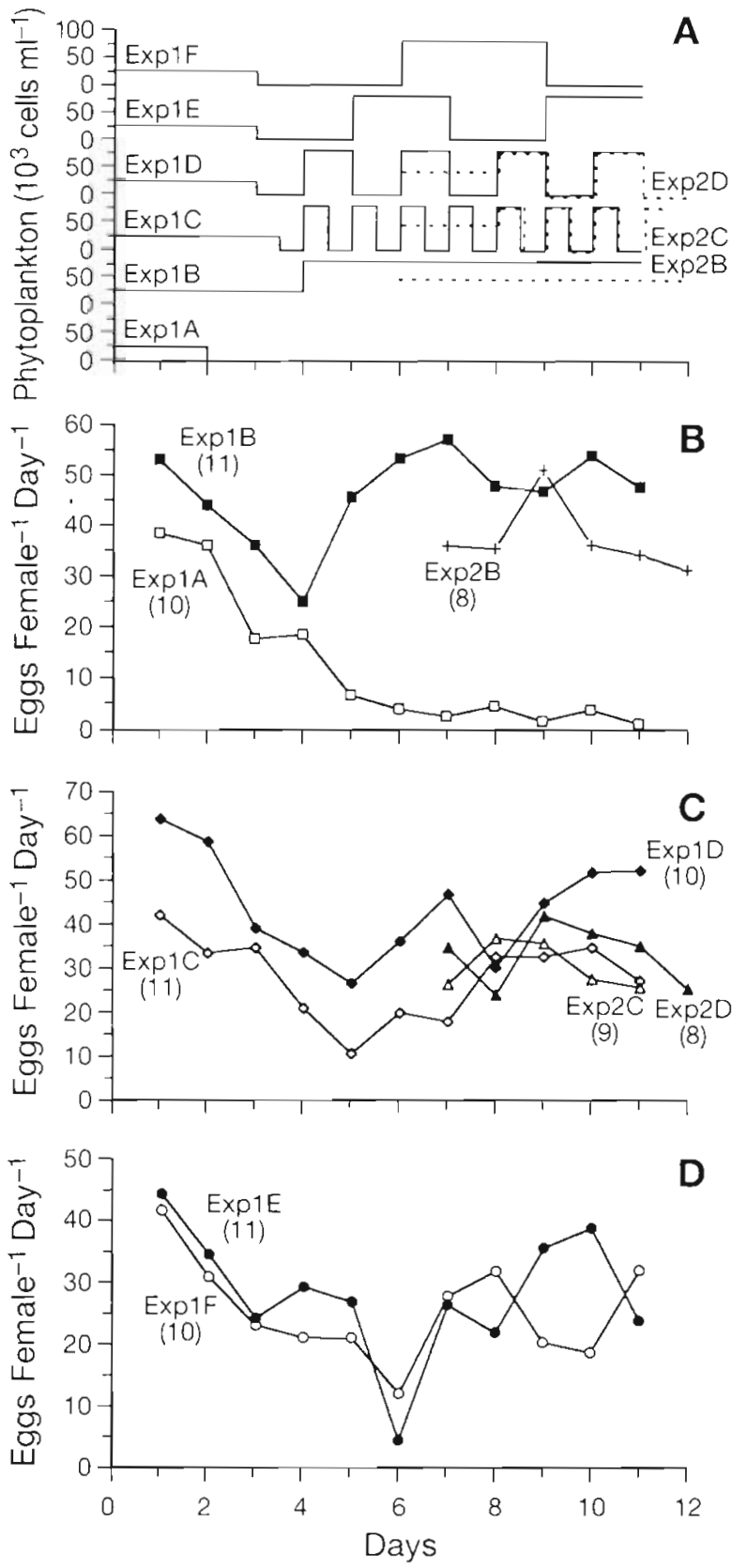

Fig. 2. Calanus finmarchicus. (A) Schedule of food concentration offered for Exp1A to Exp1F (solid lines) and Exp2B to Exp2D (dotted lines); (B) spawnıng rates for Exp1A, Exp1B and Exp2Bi $(C)$ spawning rates for Exp1C, Exp1D, Exp2C and Exp2D; (D) spawning rates for Exp1E and Exp1F. Numbers of females in brackets

Exp2Dj. In all 3 experiments food concentration was 40000 cells ml $\mathrm{m}^{-1}$ of Rhodomonas during the first $2 \mathrm{~d}$. In addition to a constant food regime (Exp2B, 8 females), 2 experiments with altemating feeding $(80000$ cells $\mathrm{ml}^{-1}$ ) versus starvation cycles of $1 / 2$ d (Exp2C, 8 females) and $1 \mathrm{~d}$ (Exp2D, 9 females) intervals were conducted. 
The nutritive value of Rhodomonas baltica in terms of carbon for Calanus finmarchicus females was estimated from our experimental results and by comparison with other observations of egg production (Hirche et al. 1997). We assumed the carbon value available for the females at a concentration of $80000 \mathrm{cells} \mathrm{mil}^{-1}$ was equal to $240 \mu \mathrm{g} \mathrm{C}^{-1}$. The resulting portion of carbon available/carbon content of $6.3 \%$ was applied then to the other algal concentrations resulting in 75 (25000), 120 (40000) and $240 \mu \mathrm{g} \mathrm{C} \mathrm{m}^{-1}$ (80000 cells $\mathrm{ml}^{-1}$ ). The resulting egg production rates were consistent with data from Hirche et al. (1997; their Fig. 6A).

Food and water were changed every $1 / 2 d$ in Exp $1 C$ and Exp2B, and daily in all other experiments by transferring cylinders with bottom screen with females to another beaker. The remaining water was sieved through $50 \mu \mathrm{m}$ and eggs were counted immediately. At the end of Exp1A-F and Exp2C, individual carbon content was determined after dipping females shortly into distilled water and storing them at $-30^{\circ} \mathrm{C}$ until analysis by a high-temperature combustion technique (Salonen 1979).

\section{EXPERIMENTAL RESULTS}

Mean egg production rates per female under different feeding regimes are presented in Fig. 2. In Exp1A-F egg production declined during the first 3 (Exp1E) or 4 (Exp1A-D,F) days, showing no difference between fed and starved females. Initial egg production of freshly caught females ranged between 35 and 64 eggs female ${ }^{-1} \mathrm{~d}^{-1}$ and declined to 16 to 33 eggs female ${ }^{-1} \mathrm{~d}^{-1}$ at Day 4 . We therefore concluded that the initial food concentration of 25000 cells $\mathrm{ml}^{-1}$ limited egg production. After increasing the food concentration of Exp1B to 80000 cells $\mathrm{ml}^{-1}$, egg production rate increased immediately and reached a plateau at the level of the initial values 3 d later, while under starvation (Exp1A) mean egg production continued decreasing (Fig. 2B). The mean total cumulative egg productions were 134.7 eggs female ${ }^{-1}(S D=11.07)$ in $\operatorname{Exp} 1 \mathrm{~A}$ and 509.18 eggs female ${ }^{-1}(\mathrm{SD}=30.18)$ in Exp1B.

With a constant food concentration of 40000 cells $\mathrm{ml}^{-1}$ (Exp2B) females produced ca 35 eggs female ${ }^{-1} \mathrm{~d}^{-1}$, except on Day 9 (Fig. 2B). On this day, we registered the largest number of eggs spawned by 1 female (107), which increased the mean value to 51.1 eggs female ${ }^{-1}$ $\mathrm{d}^{-1}$ The total cumulative egg productions ranged between 108 and 421 eggs female ${ }^{-1}$ (mean $\left.=229\right)$.

In the fluctuating food regimes Exp1C-F (Fig. 2C, D), after adjustment to 80000 cells $\mathrm{ml}^{-1}$ at Day 4 , the rates increased with some fluctuations, but never reached the initial values. Instead, final egg production ranged between 25 and 50 eggs female $\mathrm{d}^{-1}$. The comple- mentary experiments Exp2C and Exp2D yielded egg productions equal to 27 and 25.4 eggs female f $^{-1} \mathrm{~d}^{-1}$. respectively, similar to those obtained in Exp1C and Exp1D except at the end (Fig. 2C). Egg production responded to the change of food concentration usually after one or $2 \mathrm{~d}$. The mean total cumulative egg productions were 321.9 eggs female ${ }^{-1}(S D=43.99)$ in Exp1C, 484.0 eggs female ${ }^{-1}(\mathrm{SD}=31.23)$ in Exp1D, 286.5 eggs female fem $^{-1}(\mathrm{SD}=37.87)$ in Exp1E, and 316.3 eggs female $^{-1}(\mathrm{SD}=28.9)$ in Exp1F. In the complementary experiments, the mean total cumulative egg productions over 6 d were 238.75 eggs female ${ }^{-1}$ $(\mathrm{SD}=35.89)$ in Exp2B, 196.67 eggs female ${ }^{-1}(\mathrm{SD}=$ 32.74 ) in Exp2C, and 229.87 eggs female f $^{-1}(\mathrm{SD}=25.47)$ in Exp2D.

The relationship between the final carbon weight of females and their cumulative egg production during the $11 \mathrm{~d}$ of the first set of experiments is shown in. Fig. 3. The females from starvation experiment Exp1A had the lowest weights and egg production, whereas females in constant food supply $(\operatorname{Exp} 1 \mathrm{~B})$ weighed between 97 and $137 \mu \mathrm{g} \mathrm{C}$ and produced between 430 and 625 eggs, except for 1 individual with 231 eggs. This female produced eggs at a rate comparable to the majority of the other females for $4 \mathrm{~d}$ in the middle of the experimental period, otherwise it spawned very few eggs or none. Under fluctuating food regimes (Exp1C-F), the ranges of final weights ( 63 to $200 \mu \mathrm{g} \mathrm{C}$ ) and cumulated eggs (between 138 and 649) were very broad, but the data were always (except 1 case) under a line (see Fig. 3) of optimum egg production per given female weight obtained by relating the highest egg production in starving and continuous food conditions.

Clutch size and spawning interval could not be analysed directly in experiments with control intervals of $1 \mathrm{~d}$ (all experiments except Exp1C and Exp2C), as spawning interval at this temperature is $<1 \mathrm{~d}$ (Hirche et al. 1997). However, in fluctuating food regimes

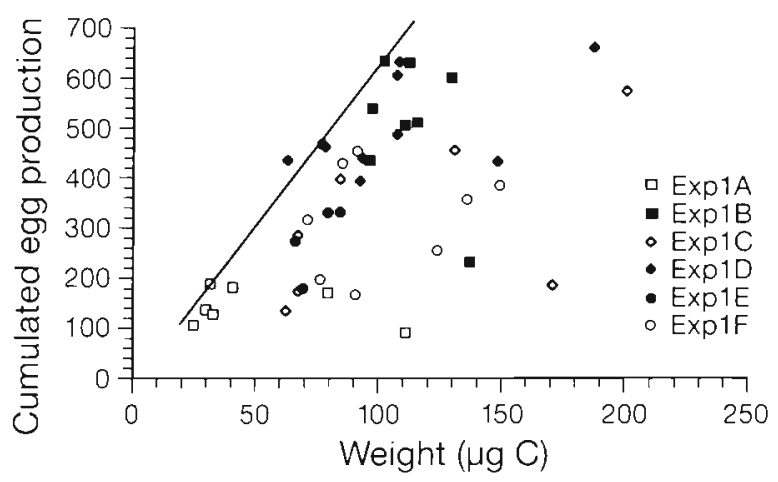

Fig. 3. Calanus finmarchicus. Cumulated egg production versus carbon weight of females at the end of Exp1A to Exp1F line corresponds to the optimum of egg production for a given weight (see text) 

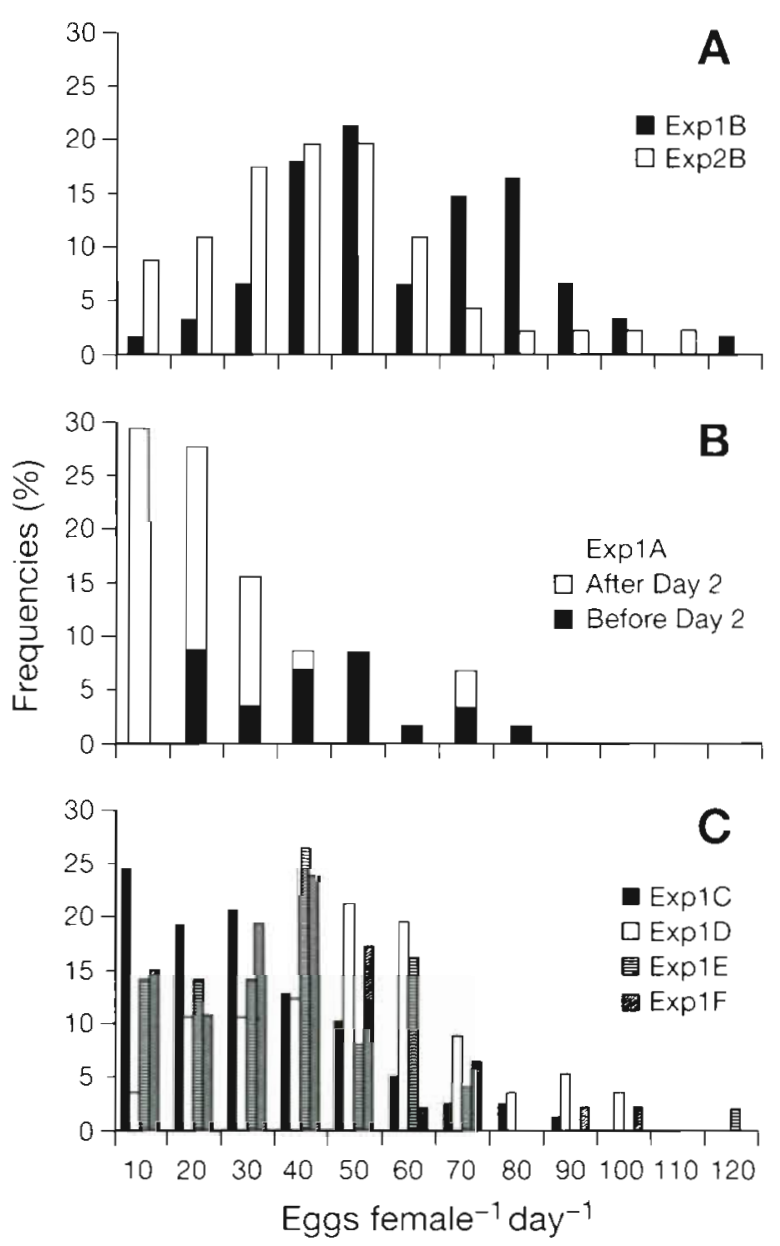

Fig. 4. Calanus finmarchıcus. Frequencies of daily egg pro-

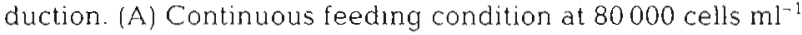
(Exp1B) calculation done for Days 5 to 11 , and at 40000 cells $\mathrm{ml}^{-1}$ (Exp2B) for Days 6 to 12. (B) Starvation conditions for (Exp1A) Days 2 to 11 (C) For Days 5 to 11 in Exp1C-F with fluctuating food conditions between 80000 and 0 cells $\mathrm{ml}^{-1}$

with controls at $1 / 2$ d intervals (Exp1C and Exp2C) we analysed the daily number of spawned eggs and the absence or presence of eggs per day. Frequencies of daily egg productions at constant 80000 cells ml $^{-1}$ (Exp1B) showed 2 peaks with one mode around 40 to 50 eggs female ${ }^{-1} \mathrm{~d}^{-1}$ and a second one around 70 to 80 eggs female ${ }^{-1} \mathrm{~d}^{-1}$ (Fig. $4 \mathrm{~A}$ ), indicating 2 clutch depositions by part of the females. At 40000 cells ml $^{-1}$ (Exp2B) only 1 peak occurred at 40 to 50 eggs female ${ }^{-1}$ $\mathrm{d}^{-1}$ (Fig. 4A), indicating 1 clutch per day. Under starvation (Fig. $4 \mathrm{~B}$ ), the frequencies of low daily egg numbers were high, especially after Day 2. At $1 / 2 \mathrm{~d}$ feeding intervals (Exp1C), 1 clutch $\mathrm{d}^{-1}$ was observed most often. The egg numbers produced during the feeding intervals (which were coincident with daylight) were 3 to 5 times higher than those produced over the starvation interval (coincident with night). The $1 \mathrm{~d}(\operatorname{Exp} 1 D), 2 \mathrm{~d}(\operatorname{Exp} 1 \mathrm{E})$ and $3 \mathrm{~d}(\operatorname{Exp} 1 \mathrm{~F})$ fluctua- tions produced similar distributions of daily egg production with an even distribution of clutches $<59$ eggs and a sharp decrease $>60$ eggs female $\mathrm{e}^{-1} \mathrm{~d}^{-1}$. The high frequencies of low egg productions compared to the reference experiment (Exp1B) are notable.

\section{MODEL RESULTS}

\section{Simulation of gonad maturation and egg production}

A basic simulation of the dynamics of internal body compartments (see Fig. 1) is presented in Fig. 5. At the beginning of the simulation, the freshly moulted
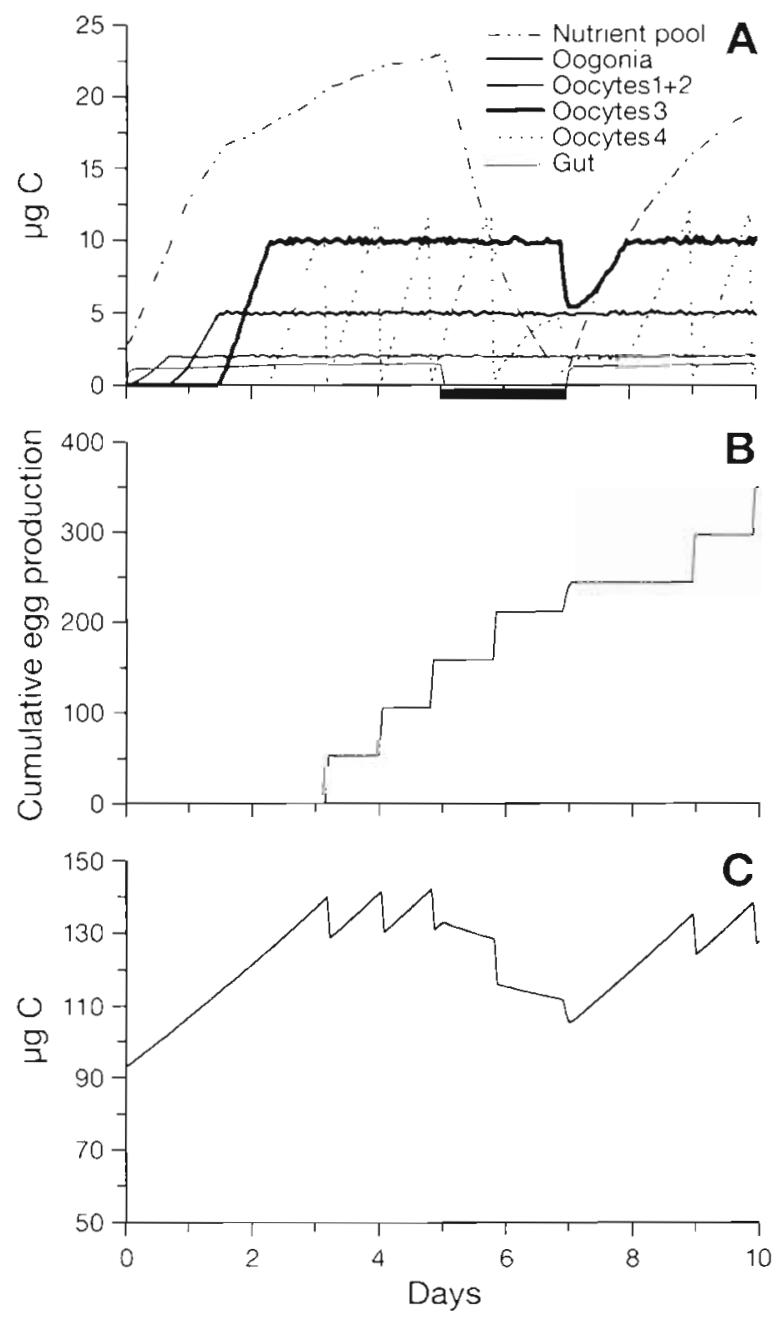

Fig. 5. Basic run of the model at $10^{\circ} \mathrm{C}$ and a food supply of $400 \mu \mathrm{CC} \mathrm{l}^{-1}$ An effect of food deprivation [thick horzontal line in $(A)]$ is introduced between Days 5 and 7 . Initial body weight was $93 \mu \mathrm{g} \mathrm{C}$, with $80 \mu \mathrm{g} \mathrm{C}$ in the structural body, $10 \mu \mathrm{g}$ $\mathrm{C}$ in the oil sac, and in $3 \mu \mathrm{g} \mathrm{C}$ in the nutrient pool. (A) Time course of carbon content of the state variables. (B) Cumulative egg production per female. (C) Time course of the total body weight 
female Calanus finmarchicus has a total carbon content of $93 \mu \mathrm{g} \mathrm{C}$, of which $80 \mu \mathrm{g} \mathrm{C}$ are in the structural body, $10 \mu \mathrm{g}$ in the oil sac, and $3 \mu \mathrm{g}$ in the nutrient pool of the hemolymph. During the simulations, the animal is exposed to a high food concentration of $400 \mu \mathrm{g} \mathrm{C}^{-1}$ for the first $5 \mathrm{~d}$, starved for $2 \mathrm{~d}$ and then re-fed $400 \mu \mathrm{g}$ $\mathrm{Cl}^{-1}$ for 3 more days (Fig. $5 \mathrm{~A}$ ) at $10^{\circ} \mathrm{C}$.

As the gut was empty at the beginning, its content increased quickly and reached equilibrium around $1 \mu \mathrm{g} \mathrm{C}$. The nutrient pool increased during the first $5 \mathrm{~d}$, with a change of the slope after $1.5 \mathrm{~d}$. The nutrient pool feeds the compartment of oogonia, which increased to a value of $2 \mu \mathrm{g} \mathrm{C}$. Then, a balance occurred between the continuous matter flux for building oogonia (FOG) and the transfer flux (T1) from 'oogonia' to 'oocytes $1+2$ ' (see Fig. 1). In the same way, the mass of 'oocytes $1+2$ ' increased and then stabilised when a flux (T2) from 'oocytes $1+2$ ' to 'oocytes3' occurred. As 'oocytes3' need more nutrients for vitellogenesis than previous stages, a higher pumping of nutrients was induced as seen in the change of the slope of the 'nutrient pool' after $1.5 \mathrm{~d}$ (Fig. 5A). When the mass of 'oocytes3' reached $10 \mu \mathrm{g}$ C, a flux (T3) from 'oocytes3' to 'oocytes4' occurred. As for 'oogonia' and 'oocytes $1+2$ ', a balance occurred between input and output of matter in the compartment 'oocytes 3 '. In contrast, the last compartment 'oocytes4' fluctuated because the mass of eggs is spawned as a clutch when the biomass of 'oocytes4' reaches $12 \mu \mathrm{g} \mathrm{C}$. The first clutch was produced $3 \mathrm{~d}$ after the beginning of the simulation, and new clutches were produced every $0.9 \mathrm{~d}$.

When deprived of food, the gut was quickly empty and the nutrient pool decreased. The compartments 'oogonia' and 'oocytes $1+2$ ' were not affected by the food deprivation because either the nutrient pool still furnished enough matter to maintain vitellogenesis and development of oocytes, or the transfer of oocytes through the compartments is stopped. The compartments 'oocytes 3 ' and 'oocytes4' were not affected by the strong reduction of nutrients during the period of food deprivation, and a clutch of 52 eggs was produced before Day 6 . When the nutrient pool became very low, just before Day 7 , the animal ejected a fraction of its 'oocytes3' and 'oocytes4', a total of 32 eggs. When food was re-introduced, the nutrient pool increased and the female resumed egg production. The first new clutch was deposited on Day 9 , which is $2 \mathrm{~d}$ after the end of the starvation period

The cumulated egg production over time (Fig. 5B) shows better that (1) the period of food deprivation induced the longest time interval between clutches (clutches 5 and 6) due to the lower flux between nutrient pool and early maturation stages, (2) an incomplete clutch is produced at Day 7 due to the release of eggs present in the compartments 'oocytes 3 ' and 'oocytes4', and (3) the delay of $2 \mathrm{~d}$ before formation of a new complete clutch on Day 9. The weight curve (Fig. 5C) shows an increase until Day 3. and then fluctuates around a mean value, due to regular egg production. The total weight immediately decreases due to food deprivation between Days 5 and 7 . The weight increases as soon as the food replenishment occurs and recovers its mean spawning weight after $2 \mathrm{~d}$.

\section{Comparison between experimental data and model simulations}

In order to compare experimental results to simulations, the daily egg production rates of Exp1A-F at
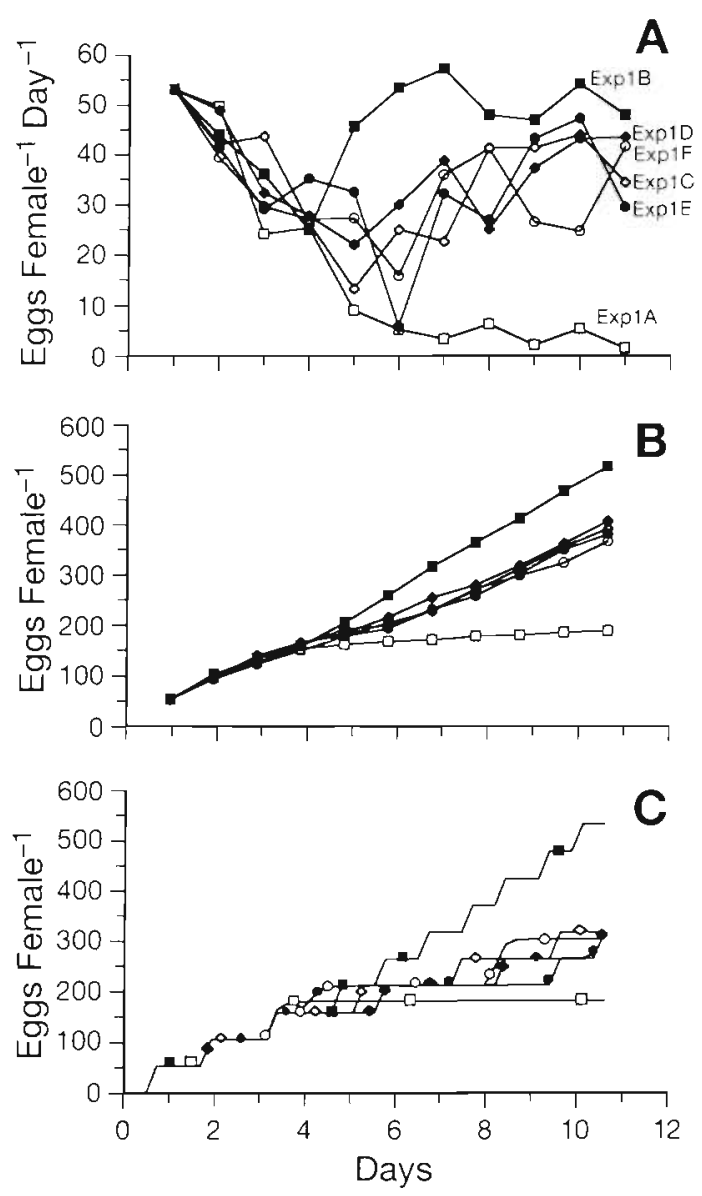

Fig. 6. Comparison of observations and simulations of egg production of Calanus finmarchicus for experiments Exp1A to Exp1F. See symbols in Fig. 3. (A) Normalized spawning rates (see Fig. 2) with reference to the initial spawning rate of Exp1B. (B) Cumulative egg production from normalized spawning rates. (C) Simulated cumulative egg production. The simulated run was initiated for $5 \mathrm{~d}$ at $400 \mathrm{\mu g} \mathrm{C} \mathrm{l} \mathrm{g}^{-1}$, before exposure to the feeding schedule shown in Fig. $2 \mathrm{~A}$ 
Day 1 have been shifted to the level of Exp1B (Fig. 6A). Cumulative egg productions over $11 \mathrm{~d}$ during Exp1A-F were calculated from the normalised spawning rates (Fig. 6B). The 4 experiments with different feeding/starvation intervals yielded between 350 and 410 eggs, between the values for starvation (190 eggs) and constant feeding (530 eggs).

The model was used to estimate egg production by simulating the experimental conditions of Exp1A-F (Fig. 6C). As the weight of freshly caught females at the beginning of the experiments was unknown, the model was run for $5 \mathrm{~d}$ at constant food concentrations of $400 \mu \mathrm{g} \mathrm{C} \mathrm{l}^{-1}$ The female then had a total weight of 131.24 $\mathrm{\mu g}$ and had already produced 3 clutches. Its structural weight was $80 \mu \mathrm{g} \mathrm{C}$, the gonad $19.0 \mathrm{\mu g} \mathrm{C}$, the nutrient pool $22.3 \mu \mathrm{g} \mathrm{C}$, and the oil sac $10 \mu \mathrm{g} \mathrm{C}$. Thereafter the model was run in the food regimes shown in Fig. 2A, between concentrations of food equal to 75 and $240 \mu \mathrm{g} \mathrm{C} \mathrm{l}^{-1}$ corresponding to the 25000 and 80000 cells $\mathrm{ml}^{-1}$ of Rhodomonas baltica, respectively.

As the model simulates the behaviour of 1 individual, the cumulated egg production over time appears as a step function, each step corresponding to a clutch Under starvation and constant food conditions, the model delivered daily rates and total cumulated egg productions which compared well to experimental results. The simulations yielded a total of 528 eggs for constant food (Exp1B) and just up to 300 eggs for the different fluctuating food regimes, which is less than observed (between 350 and 410). During starvation the total number of eggs simulated was 182 .

The observed and simulated weights at the end of the experiments are compared in Fig. 7 . The mean weight of females after the experimental treatments showed considerable variability: after starvation (Exp1A) the mean weight was $51 \mu \mathrm{g} \mathrm{C}$, whereas continuously fed females $(\operatorname{Exp} 1 B)$ had a final mean weight equal to $113.1 \mu \mathrm{g} C$. For the fluctuating conditions the mean



Fig. 7. Cumulated egg production versus average carbon weight of Calanus finmarchicus females at the end of the experiments Exp1A to Exp1F (with arrowheads) and at the end of the simulations (without arrowheads) weights ranged between 76 and $112.1 \mu \mathrm{g} \mathrm{C}$. At the end of the simulation, the weight of the starved female was $49.3 \mu \mathrm{g} \mathrm{C}$ and that of the constantly fed female $138.0 \mu \mathrm{g} C$. In fluctuating conditions, the simulations gave final weights higher than observed, ranging between 100.7 and $125.2 \mu \mathrm{g} \mathrm{C}$. Part of this discrepancy may be explained by the fact that due to the weight of the clutch there is a $12 \mu \mathrm{g} C$ difference between freshly spawned females and those close to spawning

\section{Effect of temperature}

The effect of temperature on egg production was tested in simulations at 0,5 and $10^{\circ} \mathrm{C}$ and at $400 \mu \mathrm{g} \mathrm{C}$ $\mathrm{l}^{-1}$. The cumulative egg production and weight fluctuations are shown in Fig. 8. The initial structural weight in each simulation corresponded to the critical spawning weight, which is temperature dependent (see 'Model conceptualisation'). At $10^{\circ} \mathrm{C}$, the weight stabilised at around $140 \mu \mathrm{g} \mathrm{C}$ and 1 to 2 clutches were produced daily, whereas at 5 and $0^{\circ} \mathrm{C}$, the weights reached 155 and $178 \mu \mathrm{g} \mathrm{C}$, respectively, and a clutch was produced after 1 or $2 \mathrm{~d}$, respectively. The respective spawning intervals were $0.77,1.33$ and $2.33 \mathrm{~d}$ at 10,5 and $0^{\circ} \mathrm{C}$. Clutch sizes changed slightly with 52.94 52.82 and 52.76 eggs clutch ${ }^{-1}$ for the same temperatures. At the beginning of egg production, the weight showed only small fluctuations at all temperatures. The mass loss of each clutch does not show up because
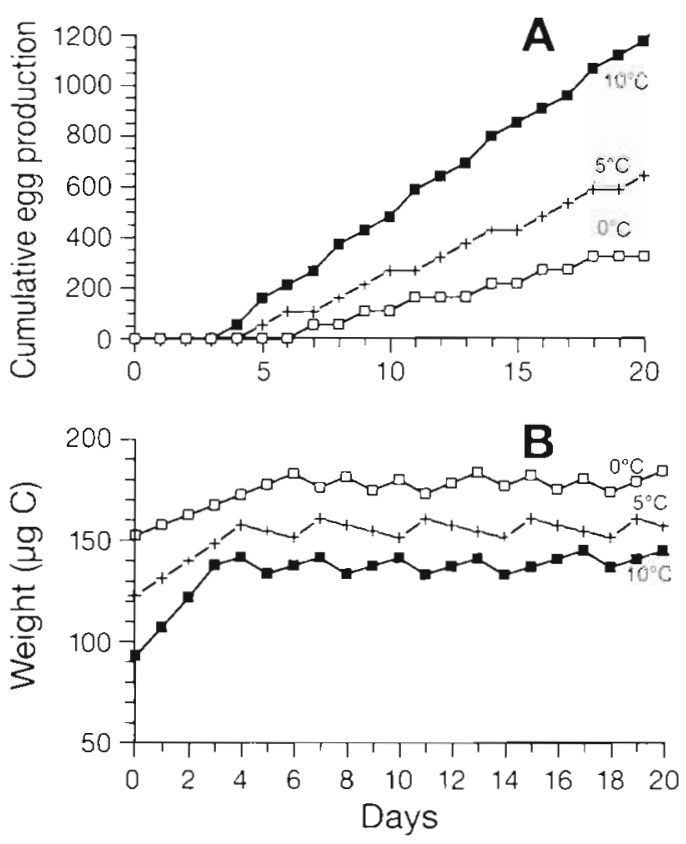

Fig. 8. Simulated (A) cumulative egg production and (B) total weight variations at 10,5 and $0^{\circ} \mathrm{C}$ 
the curves are built with 1 value per day. The biomass of daily egg production varied overall by $5.20,9.13$, and $15.81 \mu \mathrm{g} \mathrm{C} \mathrm{d}^{-1}$, and the daily carbon specific egg production by $2.92,5.89$, and $11.29 \mathrm{~d}^{-1}$ at 0.5 and $10^{\circ} \mathrm{C}$, respectively. From these values a $Q_{10}$ of 3.07 was calculated from the model.

\section{Effect of starvation and re-feeding}

In a complementary set of simulations the behaviour of the model after a longer starvation period was studied. Hirche et al. (1997) conducted egg production experiments with females kept for $6 \mathrm{~d}$ at surplus food concentration, then $12 \mathrm{~d}$ without food, and then fed 9 food concentrations for $9 \mathrm{~d}$ (their experiment EXP II, their Fig. $4 \mathrm{C}$ ). Our model was run using the same experimental conditions, but with 5 rather than 9 different food concentrations for the last $9 \mathrm{~d}$. The cumulated egg production and the time-course of body and gonad weights are presented in Fig. 9. To obtain con-
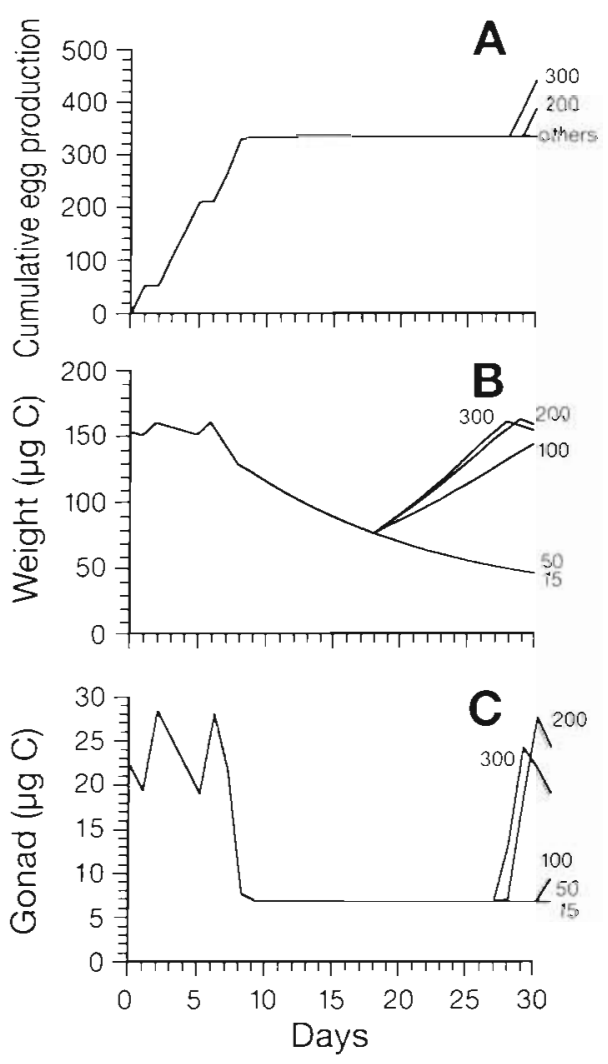

Fig. 9. Simulated (A) cumulative egg productions of Calanus finmarchicus females, (B) carbon body weight and (C) gonad weight at different food conditions. All females were kept at optimal food conditions from Days 0 to 6 , then without food between Days 6 and 18. After Day 18, 5 food concentrations were offered: $15,50,100,200$ and $300 \mathrm{\mu g} \mathrm{Cl}^{-1}$ (see complementary explanations in Hirche et al. 1997) tinuously spawning females, the model was first run for $5 \mathrm{~d}$ at $240 \mathrm{\mu g} \mathrm{Cl}^{-1}$ before being forced by the experimental conditions. During the first $6 \mathrm{~d}$ of the experiment, the simulated female weight was almost constant around $155 \mu \mathrm{g} \mathrm{C}$, then decreased as soon as the food disappeared. Egg production increased regularly at the beginning, and stopped $3 \mathrm{~d}$ after the removal of food. This time lag corresponded to a decrease of gonad weight from 28 to $5 \mu \mathrm{g}$ C over $3 \mathrm{~d}$. The total egg production during the first $10 \mathrm{~d}$ stabilised around 330 eggs, which was lower than the production obtained by Hirche et al. (1997; around 380 eggs at Day 10). In their experiment, the clutches during the first $6 \mathrm{~d}$ were extremely large (their Fig. 6d).

\section{DISCUSSION}

\section{Experiments}

Rhodomonas baltica was not an optimal food for Calanus finmarchicus. Its equivalent spherical diameter is between 6.9 and $8 \mu \mathrm{m}$ (Berggreen et al. 1988, Nejstgaard et al. 1995) and therefore at the lower size limit of the filtering capacity of Calanus females (Frost 1972). In contrast to Nejstgaard et al. (1995), who obtained a maximum feeding rate at $25000 \mathrm{cells} \mathrm{ml}^{-1}$ (see their Fig. 6), egg production decreased strongly at this concentration and instead very high algal concentrations were necessary to obtain high egg production. We assumed that only a small fraction $(6.3 \%)$ of the cells, probably the largest cells in the culture, were available for the females (see 'Material and methods of experiments' for estimation of the available fraction).

Egg production was closely related to food concentration, indicating consistency among experiments. The egg production rates obtained in freshly caught females (mean 47.2, SD 8.6) and after acclimation at 80000 cells $\mathrm{ml}^{-1}$ (Exp1B; mean 51.2, SD 4.21 for Days 7 to 12) are comparable to those of Runge $(1985)$ at $10^{\circ} \mathrm{C}$. Bamstedt (1988) observed similar rates in March in Rannefjord, Norway, a location near our sampling site. Diel \& Tande (1992) reported 21 to 23 eggs female ${ }^{-1} \mathrm{~d}^{-1}$ at $5^{\circ} \mathrm{C}$. Higher rates (73.4 eggs female ${ }^{-1} \mathrm{~d}^{-1}$ ) were reported by Hirche et al. (1997) at $8^{\circ} \mathrm{C}$. However, carbonspecific production was very similar, as their females were much heavier. Experiments under fluctuating food conditions have not been reported yet for Calanus finmarchicus.

Hirche et al. (1997) found that clutch size was independent of the external variables and that mainly the spawning interval regulated egg production. In our experiments, under conditions of starvation and fluctuating food supply, the frequency of small clutches increased (Fig. 4). Thus, the production of small 
clutches appears to be a transition process in the individual spawning dynamics induced by environmental fluctuations. This assumption is supported when the periods of egg production in the starvation experiment Exp1A (Fig. 4B) are split. During the first $2 \mathrm{~d}$ of starvation, females produced a mean of 50 eggs, but variability was high and frequency distribution of clutch size resembled experiments with fluctuating food conditions. After the second day eggs were produced only occasionally, and clutch size was mostly between 10 and 30 eggs, as observed by Hirche et al. (1997; their Fig. 10). If these results are compared with individualbased model results, it is important to note that the mean rate of individual egg production does not represent what happens at the individual level during starvation. The very sporadic egg deposition at the individual level is distorted by the mean value.

The range of female weights $(25$ to $200 \mu \mathrm{g} \mathrm{C}$ ) at the end of the different experiments was extremely large compared with the range of female weights observed in the field (Carlotti et al. 1993). The lightest individuals were obtained from the starvation experiment (Exp1A). Such low weights were not mentioned before: they correspond to the weight of a copepodite 5 (C5). Two of the starved females had final weights above $80 \mu \mathrm{g} \mathrm{C}$, a value considered in the model as the critical moulting weight of $\mathrm{C} 5$ at $10^{\circ} \mathrm{C}$. The most productive females (500 to 640 eggs) of the constant feeding experiment (Exp1B) had weights around $110 \mu \mathrm{g} \mathrm{C}$, a high weight value for females at $10^{\circ} \mathrm{C}$ as compared with field observations (Carlotti et al. 1993). Thus, well-fed animals both accumulated body matter and produced eggs, suggesting that 80000 cells ml ${ }^{-1}$ was an optimal food concentration. One female of Exp1B had a low egg production compared to the others, but a higher weight. From the fluctuating food experiments, we obtained large ranges both of weights and eggs produced, but we never obtained females with high production and extremely low weights. Our experimental results suggest that the females caught in April in Korsfjorden did not use lipid reserves to damp fluctuations of resources and, thus, to maintain continuous egg production.

\section{Model concept}

It was the aim of this study to build a complete model of the egg production of Calanus finmarchicus. Its different parts have not been equally validated. We can distinguish (1) the representation of metabolic and growth processes, (2) the representation of the gonad and the different growth and maturation processes, (3) the nutrient pool in the hemolymph, and (4) the representation of the reserve compartment.
(1) The metabolic rates of ingestion, assimilation, egestion and respiration used here have often been measured (i.e. Gamble 1978) and tested with models (Steele 1974, Carlotti \& Radach 1996). These coefficients permit correct representation of the growth of adult females of Calanus finmarchicus (Carlotti \& Radach 1996).

(2) We have considered 4 oocyte developmental stages in the gonad, according to recent studies of Niehoff \& Hirche (1996). For a female spawning regularly (e.g. Days 3 to 5 in Fig. 5) the maturation compartments reach stable masses at 2,5,10 and $12 \mu \mathrm{g} \mathrm{C}$, respectively. The masses of compartments oogonia, oocytes $1+2$, and oocytes 3 ' are hypothetical; they were estimated from size measurements of different oocyte stages by Niehoff and Hirche (1996). The size of compartment 'oocytes 4 ' is equivalent to the size of 1 clutch of 50 eggs, assuming an egg carbon content of $0.23 \mu \mathrm{g}$ C. Validation of the transfer of oocytes through the different developmental stages (T1 to T3; Fig. 1) is difficult. We obtained a value of around $0.885 \mathrm{~d}$ at $10^{\circ} \mathrm{C}$ as compared to $0.75 \mathrm{~d}$ at $5^{\circ} \mathrm{C}$ measured by Niehoff \& Hirche (1996). The energetic processes linked to oogonia building and oocyte maturation consist mainly of the accumulation of organic and inorganic constituents of yolk in the oocytes (vitellogenesis) of copepods. They have not been described yet quantitatively for copepods.

(3) In the model, we represented a nutrient compartment which plays a central role in the distribution of matter to either the structural body, or the gonads or the reserves compartment. Blades-Eckelbarger and Youngbluth (1984) assumed an uptake of material from the hemolymph by 'oocytes3' of Labidocera destiva, and Niehoff \& Hirche (1996) found indications for this flux of matter for Calanus finmarchicus. However, no information was found on the biochemical composition of the hemolymph of copepods. Spaargaren \& Haefner (1994) studied the variations of protein, lipid and carbohydrate content of the hemolymph, ovary, and hepatopancreas of the brown shrimp Crangon crangon relative to ovarian development. Because hemolymph represents a means of transport between organs and equals $37 \%$ of the body wet weight of $C$. crangon, the content of biochemical substances in the hemolymph is higher than contents in hepatopancreas and ovaries together. Comparable results have been observed for decapods (see review by Harrison 1990).

There is evidence that a real cost is associated with reproduction. Kiørboe et al. (1985) estimated the energetic cost to build $1 \mathrm{\mu g}$ egg $\mathrm{C}$ of Acartia tonsa equal to $0.188 \mu \mathrm{g} \mathrm{C}$. If the same ratio is applied to Calanus finmarchicus, a production of 50 eggs $\mathrm{d}^{-1}$ will induce a daily energetic cost of $2.16 \mu \mathrm{g} \mathrm{C}$. The model predicts an energy cost for egg production (50 eggs female $\mathrm{e}^{-1} \mathrm{~d}^{-1}$ ) equal to $2.61 \mu \mathrm{g} \mathrm{C} \mathrm{d}^{-1}$. 
(4) In our simulations no material accumulated in the oil sac. The main reason is that the arbitrarily fixed threshold content of material in the hemolymph was never reached. The knowledge of the fluxes between oil sac and other compartments is weak, but it seems that the reserves compartment does not really play a role in the vitellogenesis 2 of Calanus finmarchicus (Plourde \& Runge 1993, Ohman \& Runge 1994). To simulate variations of food over short periods as presented in this paper, it is possible that the nutrient pool in the hemolymph is sufficient to serve as a buffer. It is known that the oil sac is used to withstanding longterm starvation (Håkanson 1984) Because the experimental females caught in the fjord in April were also spawning eggs on freshly assimilated food, we did not increase the complexity of the model by taking into account the role of the oil sac in the egg production. For long-term or yearly simulations, the flux of matter from the oil sac to the nutrient pool has to be considered. The genital tractus and gonads are built in early winter time using organic content of the oil sac (Tande \& Hopkins 1981, Niehoff \& Hirche 1996). In this model, we did not consider hormonal processes, nor changes in biochemical components (Pillay \& Nair 1973).

\section{Model results}

The simulations of individual trophodynamics and egg production under different food conditions
(Exp1A-F) reflected well the experimental time-course of egg production (Fig. 6) and final weights (Fig. 7). Both experiments and simulations showed that under fluctuating conditions (Fig. 6B, C between Days 5 and 11) the mean egg production is the same regardless of the fluctuation frequency, if mean food concentration is the same.

The model suggests an interesting explanation for the response time of egg production when food is re. stored at different concentrations (Fig. 9): after a large weight decrease during the starvation period, females resume their growth if the food concentration is sufficient. At 200 and $300 \mu \mathrm{g} \mathrm{Cl}^{-1}$, the females succeed in spawning a clutch before Day 30. At $100 \mu \mathrm{g} \mathrm{C} \mathrm{I}^{-1}$ the critical spawning weight is almost completely recovered at Day 30, while spawning was not resumed yet. These results are comparable to the experimental results shown by Hirche et al. (1997; their Fig. 4c).

The simulation results obtained at different temperatures for mean weights, daily egg productions, spawning interval and carbon specific production are consistent with other data (Table 3). The cumulated egg production at 0 and $5^{\circ} \mathrm{C}$ are also in the ranges of observations (Hirche 1990, his Fig. 1; Hirche et al. 1997; their Fig. 1)

The good agreement of final mean weights, despite the unavoidable individual variability (Fig. 3), confirms that the mathematical representation of metabolic and growth processes presented here is sound. The model

Table 3. Comparison between simulated results and observed data from other studies for weights and egg production parameters of Calanus finmarchicus, at different temperatures. Simulated carbon-specific egg production has been calculated using either the total weight or the critical weight, as done by McLaren \& Leonard (1995)

\begin{tabular}{|c|c|c|c|c|c|c|c|}
\hline Source & $\begin{array}{l}\text { Temperature } \\
\left({ }^{\circ} \mathrm{C}\right)\end{array}$ & $\begin{array}{l}\text { Total } \\
\text { weight } \\
(\mu g \mathrm{C})\end{array}$ & $\begin{array}{l}\text { Critical } \\
\text { weight } \\
(\mu g C)\end{array}$ & $\begin{array}{l}\text { Number } \\
\text { of eggs }\end{array}$ & $\begin{array}{l}\text { Spawning } \\
\text { interval } \\
\text { (d) }\end{array}$ & $\begin{array}{l}\text { Carbon-specific } \\
\text { egg production } \\
(\% \mu \mathrm{g} \mathrm{C} / \mu \mathrm{g} \mathrm{C})\end{array}$ & $\begin{array}{l}\text { Carbon-specific } \\
\text { egg production with } \\
\text { critical weight } \\
(\% \mu g \mathrm{C} / \mu \mathrm{g} \mathrm{C})\end{array}$ \\
\hline Model & $\begin{array}{r}0 \\
5 \\
10\end{array}$ & $\begin{array}{l}178 \\
155 \\
140\end{array}$ & $\begin{array}{c}139.4 \\
109.7 \\
80\end{array}$ & $\begin{array}{l}22.64 \\
39.71 \\
68.75\end{array}$ & $\begin{array}{l}2.33 \\
1.33 \\
0.77\end{array}$ & $\begin{array}{r}2.92 \\
5.89 \\
11.29\end{array}$ & $\begin{array}{r}3.73 \\
8.32 \\
14.11\end{array}$ \\
\hline Nielsen \& Hansen (1995) & 5) & 160 & & 20 & & 2.87 & \\
\hline Hirche et al. (1997) & $\begin{array}{l}0 \\
0 \\
2 \\
5 \\
8 \\
5 \\
5\end{array}$ & $\begin{array}{c}127 \\
- \\
186 \\
163 \\
198\end{array}$ & & $\begin{array}{l}22.3 \\
22.9 \\
44.7 \\
52.5 \\
53.8 \\
39.8 \\
46.9\end{array}$ & $\begin{array}{l}2.3 \\
2.2 \\
1.6 \\
0.9 \\
0.7 \\
1.4 \\
1.6\end{array}$ & $\begin{array}{l}4 \\
3 \\
3.4 \\
7.4 \\
8.5\end{array}$ & \\
\hline Hirche $(1.990)$ & 0 & 100 & & $19.9-24.4$ & $2.06-2.37$ & 5.5 & \\
\hline Ohman \& Runge (1994) & ca 8 & 222 & & $11-45$ & & $1.14-4.6$ & \\
\hline Plourde \& Runge (1993) & $\begin{array}{c}1 \\
5.5 \\
7-9\end{array}$ & $160-220$ & & $\begin{array}{l}30 \\
43 \\
60-80\end{array}$ & & $8-11$ & \\
\hline Diel \& Tande (1992) & 5 & 86 & & $21-23$ & & 5.7 & \\
\hline
\end{tabular}


clearly shows that variation of food induces immediate changes in weight but delayed response of egg production (Fig. 5). After a certain duration of food deprivation, when the threshold of the nutrient pool content is reached, the female spawns smaller clutches. This is consistent with our experiments involving starvation and fluctuating food (cf Fig. 4). It is also consistent with observations of Peterson (1988), showing that the egg production of Calanus marshallae ceased completely after $1 \mathrm{~d}$ of starvation, and was re-initiated after an interval of 0.4 times the starvation interval. The response time of $C$. finmarchicus seems to be longer. Based on observations of clutches in different food concentrations, Peterson (1988) suggested that 'egg production is a 2 -step physiological process, one step involving the production of a clutch of eggs on a predetermined schedule, and the second step involving the energetic controlling the number of eggs within that clutch'. We also consider these 2 steps in egg formation.

\section{CONCLUSIONS}

From the simulations presented and the comparison with experimental data, the conceptual scheme of the present model cannot be rejected. The model provides dynamical explanations of data. It emphasises the necessity to analyse daily egg production, both in correlation with external (food and temperature variations) and internal (e.g. individual weight) factors. The reserves of the oil sac in adult females seem mainly to play a role in coping with the seasonal variation of food.

Sciandra et al. (1990) presented the first model of reproduction of calanoid copepods which represented a non-linearity between fluctuations of food and egg production. They suggested the use of mathematical formulations which correctly simulate the time lag between variations of input and output. Our model represents a new step, because (1) it couples growth and egg production of a female Calanus finmarchicus, a copepod with a more complex reproductive strategy; (2) it takes into account the influence of both food and temperature; and (3) it represents steps of egg formation which can be experimentally observed. In Sciandra et al.'s (1990) model no clutches were simulated, although Centropages typicus seems to produce clutches of eggs (Carlotti pers. obs.). Moreover, the data used to validate Sciandra et al.'s (1990) model were not from experiments with single females, where mean values can induce misinterpretations. Also, their model delivered matter content in the gut equal to the matter content in the gonad (their Fig. 8), which is not realistic.
As egg production is a key process in population dynamics and in estimation of secondary production, we suggest relating results of egg production to a mean food concentration as measured over a period of several days and not to the food measurement on the sampling day alone. Population dynamics models taking into account the individual metabolic processes which influence growth and development still have a representation of the egg production process which is too simple (Carlotti \& Radach 1996) and should also represent important physiological time-lags (Tester \& Turner 1990).

Acknowledgements. This work was funded by the Commission of the European Community under contracts MAS2 CT93-0057 (ESOP) of the MAST-Il Programme and MAS3CT95-0039 (TASC) of the MAST-III Programme. We appreciate the possibility to use the facilities of the Marinbiologisk Feltstasjon, Espegrend, University of Bergen, Norway. J. Wegner measured carbon contents. Thanks to B. Niehoff for useful discussions on gonad maturation and to C. Miller for editing of and comments on the manuscript. This is publication no. 1206 of the Alfred Wegener Institute for Polar and Marine Research, Bremerhaven and is a contribution of LOBEPM (Laboratoire d'Océanographie Biologique et d'Ecologie du Plancton Marin).

\section{LITERATURE CITED}

Bâmstedt U (1988) Ecological significance of individual variability in copepod bioenergetics. Hydrobiologia 167/168: $43-59$

Berggreen V. Hansen B, Kiørboe T (1988) Food size spectra, ingestion and growth of the copepod Acartia tonsa during development: implication for determination of copepod production. Mar Biol 99:341-352

Blades-Eckelbarger P, Youngbluth MJ (1984) The ultrastructure of oogenesis and yolk formation in Labidocera aestiva (Copepoda: Calanoida). J Morphol 179:33-46

Carlotti F, Krause M, Radach G (1993) Growth and development of Calanus finmarchicus taking into account the effect of temperature. Limnol Oceanogr 38:1125-1134

Carlotti F, Radach G (1996) Seasonal dynamics of phytoplankton and Calanus finmarchicus in the North Sea as revealed by a couplied one-dimensional model. Limnol Oceanogr 41:522-539

Corkett CJ, McLaren IA (1969) Egg production and oil storage by the copepod Pseudocalanus in the laboratory. J Exp Mar Biol Ecol 3:90-105

Diel S, Tande K (1992) Does the spawning of Calanus finmarchicus in high latitudes follow a reproductible pattern? Mar Biol 113:21-31

Frost BW (1972) Effects of size and concentration of food particles on the feeding behavior of the marine planktonic copepod Calanus pacificus. Limnol Oceanogr 17:805-815

Frost BW (1985) Food limitation of the planktonic marine copepods Calanus pacificus and Pseudocalanus sp. in a temperature fjord. Arch Hydrobiol Beih Ergeb Limnol 21:1-13

Gamble JC (1978) Copepod grazing during a declining spring phytoplankton bloom in the northern North Sea. Mar Bio] 49:303-315

Håkanson JL (1984) The long and short term feeding condi- 
tion in field-caught Calanus pacificus, as determinined from the lipid content. Limnol Oceanogr 29:794-804

Hansen B, Tande KS, Berggreen UC (1990) On the trophic fate of Phaeocystis pouchetii (Hariot). III. Functional responses in grazing demonstrated on juvenile stages of Calanus finmarchicus (Copepoda) fed diatoms and Phaeocystis. J Plankton Res 12:1173-1187

Harrison KE (1990) The role of nutrition in maturation, reproduction and embryonic development of decapod crustacean: a review. J Shellfish Res 9:1-28

Hirche HJ (1987) Temperature and plankton. II. Effect on respiration and swimming activity in copepods from the Greenland Sea. Mar Biol 94:347-356

Hirche HJ (1990) Egg production of Calanus finmarchicus at low temperature. Mar Biol 106:53-58

Hirche HJ (1.996) The reproductive biology of the marine copepod, Calanus finmarchicus - a review. Ophelia 44 111-128

Hirche HJ, Kattner G (1993) Egg production and lipid content of Calanus glacialis in spring: indication of a fooddependent and food-independent reproductive mode. Mar Biol 117:615-622

Hirche HJ, Meyer U, Niehoff B (1997) Egg production of Calanus finmarchicus-effect of temperature, food and season. Mar Biol 127:609-620

Ianora A, Scotto di Carlo B, Mascellaro P (1989) Reproductive biology of the planktonic copepod Temora slylifera. Mar Biol 101:187-194

Kiorboe T, Møhlenberg F, Hamburger K (1985) Bioenergetics of the planktonic copepod Acartia tonsa between feeding egg production and respiration, and composition of specific dynamic action. Mar Ecol Prog Ser 26:85-97

Klein Breteler WCM, Gonzales SR (1982) Influence of cultivation and food concentration on body length of calanoid copepods. Mar Biol 71:157-161

Marshall SM (1949) On the biology of small copepods in Loch Striven. J Mar Biol Ass UK 28:45-122

Marshall SM, Orr AP (1955) The biology of a marine copepod Oliver \& Boyd, Edinburgh

McLaren IA, Leonard A (1995) Assessing the equivalence of growth and egg production of copepods. ICES J Mar Sci $52: 397-408$

Nejstgaard JC, Båmsted U, Bagøien E, Solberg PT (1995) Algal constraints on copepod grazing. Growth state, toxicity, cell size, and season as regulating factors. ICES J Mar Sci 52:347-357

Niehoff B. Hirche HJ (1996) Oogenesis and gonadogenesis in the copepod Calanus finmarchicus and the prediction of egg production from preserved samples. Polar Biol 16: $601-612$

Nielsen TG, Hansen B (1995) Plankton community structure and carbon cycling on the western coast of Greenland during and after the sedimentation of diatom bloom. Mar Ecol Prog Ser 125:238-257

Nival S, Pagano M Nival P (1990) Laboratory study of the spawning rate of the calanoid copepod Centropages typicus: effect of fluctuating food concentration. J Plankton Res 12:535-547

Ohman M, Runge J (1994) Sustained fecundity when phytoplankton resources are in short supply: omnivory by Calanus finmarchicus in the Gulf of St. Lawrence. Limnol Oceanogr 39:21-36

Paffenhöfer GA (1971) Grazing and ingestion rates of nauplii, copepodids and adults of the marine planktonic copepod Calanus helgolandicus. Mar Biol 11:286-298
Peterson WT (1988) Rates of egg production by the copepod Calanus marshallae in the laboratory and in sea off Oregon, USA. Mar Ecol Prog Ser 47:229-237

Pillay KK, Nair NB (1973) Observations on the biochemical changes in gonads and other organs of Ucca annulipes, Portunus pelagicus and Metapenaeus affinis (Decapoda: Crustacea) during the reproductive cycle. Mar Biol 18: $167-198$

Plourde S, Runge JA (1993) Reproduction of the planktonic copepod Calanus finmarchicus in the lower St. Lawrence Estuary: relation to the cycle of phytoplankton production and evidence for a Calanus pump. Mar Ecol Prog Ser 102:217-227

Razouls C, Guinness C (1973) Variation annuelles quantitatives de deux especes dominantes de copépodes planctonique Centropages typicus et Temora stylifera de la région de Banyuls: cycle biologique et estimation de la production. II. Variation bidimentionnelles et mesure de la croissance. Cah Biol Mar 14:413-427

Razouls S, Nival P, Nival S (1987) Development of the genital system in the copepodid stages of the calanoid copepod Temora stylifera Dana. J Mar Biol Ass UK 67:653-661

Razouls S, Nival S, Nival P (1986) La reproduction de Temora stylifera: ses implications anatomiques en relation avec le facteur nutrition. J Plankton Res 8:875-889

Runge JA (1984) Egg production of the marine planktonic copepod, Calanus pacificus Brodsky: laboratory observations. J Exp Mar Biol Ecol 74:53-66

Runge JA (1985) Egg production rates of Calanus finmarchicus in the sea off Novia Scotia. Arch Hydrobiol Beih Ergeb Limnol 21:33-40

Runge JA (1988) Should we expect a relationship between primary production and fisheries? The role of copepod dynamics as a filter of trophic variability. Hydrobiologia 167/168:61-71

Salonen K (1979) A versatile method for rapid and accurate determination of carbon by high temperature combustion. Limnol Oceanogr 24:177-185

Sciandra A, Gouzé JL, Nival P (1990) Modelling the reproduction of Centropages typicus (Copepoda: Calanoida) in a fluctuating food supply, effect of adaptation. J Plankton. Res 12:542-572

Smith SL, Lane PVZ (1985) Laboratory studies on the marine copepod Centropages typicus, egg production and development rates. Mar Biol 85:153-162

Spaargaren $\mathrm{DH}$, Haefner PA Jr (1994) Interactions of ovary and hepatopancreas during the reproductive cycle of Crangon crangon (L.). II. Biochemical relationships. J Crustacean Biol 14:6-19

Steele JH (1974) The structure of marine ecosystem. Harvard University Press, Cambridge

Tande KS, Båmstedt U (1985) Grazing rates of the copepods Calanus glacialis and C. finmarchicus in arctic waters of the Barents Sea. Mar Biol 87:251-258

Tande KS, Hopkins CCE (1981) Ecological investigations on the zooplankton community of Balsfjorden, northern Norway: the genital system in Calanus finmarchicus and the role of gonad development in overwintering strategy. Mar Biol 63:159-164

Tester PA, Turner JT (1990) How long does it take copepods to make eggs? J Exp Mar Biol Ecol 141:169-182

Vidal J (1980) Physioecology of zooplankton. I. Effects of phytoplankton concentration, temperature and body size on the growth rate of Calanus pacificus and Pseudocalanus. Mar Biol 56:111-134 


\title{
Diel, seasonal and ontogenetic variations in the vertical distributions of four marine copepods
}

\author{
T. Falkenhaug ${ }^{1, *}$, K. S. Tande ${ }^{1}$, T. Semenova ${ }^{2}$ \\ ${ }^{1}$ Norwegian College of Fishery Science, University of Tromsø, N-9037 Tromsø, Norway \\ ${ }^{2}$ Institute of Oceanology, Russian Academy of Sciences, Krasikova St. 23, Moscow 117218, Russia
}

\begin{abstract}
Diel and seasonal variations in the vertical distributions of Calanus finmarchicus, Metridia longa, M. lucens and Chiridius armatus in Malangen, northern Norway, were determined from February until December 1992. The vertical behaviour differed among the species and among the different stages of a single species. The vertical distribution of $C$. finmarchicus was dominated by seasonal rather than diel vertical migration, and this species was found in surface waters during the spring phytoplankton bloom (March to May), and at the bottom of the fjord in the fall and winter. Metridia spp. were generally consistent diel vertical migrators. However, $M$. longa usually stayed deeper and had a larger migration amplitude than $M$. lucens. $M$. longa was more deeply distributed in the winter than during the summer, while $M$. lucens showed no such seasonal trend. The vertical behaviour of $C$. armatus was related to the seasonal change in day length, and diel vertical migration was strong in periods of large day/night contrast (spring and autumn), but ceased during the periods of midnight sun and winter darkness. During the summer C. armatus stayed deep both day and night. Diel vertical behaviour in young stages of all 4 species was weak or undetectable by the sampling method used. Younger stages of C. finmarchicus and Metridia spp. remained higher in the water column, while the opposite was observed in C. armatus. While seasonal variations in vertical behaviour are related to variations in food and light conditions, inter- and intraspecific differences may be due to life history, diet and susceptibility to predation.
\end{abstract}

KEY WORDS: Zooplankton - Copepods - Vertical distribution · Vertical migration Fjords - Northern Norway

\section{INTRODUCTION}

The water column of the ocean provides a diverse habitat gradient in which light, temperature, food and predation risk all change with depth (e.g. Banse 1964, Mullin 1979). Thus, the vertical distribution of zooplankton may be regarded as a process of habitat selection, in which the organism must trade off various selective forces (Giske et al. 1990): (1) visual predation from fish, (2) non-visual predation from carnivorous zooplankton, (3) the vertical distribution of food, and (4) the cost of migration. The outcome of this trade-off is influenced by environmental factors such as light (Russel 1927, Cushing 1951, Ringelberg 1991), abundance of food (Pearre 1973, Huntley \& Brooks 1982), predator abundance (Bollens \& Frost 1989, Lampert

•E-mail: tonef@nfh.uit.no
1989, Ohman 1990) and hydrography (Banse 1964, Pearre 1979). Furthermore, inter-and intraspecific differences in the response to these environmental factors are due to differences in fecundity (Gabriel \& Thomas 1988), size (Landry 1978, Sullivan 1980, Yen 1985), behaviour (Gerritsen \& Strickler 1977, Zaret 1980, Greene 1988, Ramcharan \& Sprules 1991) and pigmentation (Kerfoot 1985). Temporal variations in environmental factors combined with species-specific responses to these changes enhance diel and seasonal variations in the vertical distribution of zooplankton organisms. The vertical distribution and migration of zooplankton has been studied since the early years of plankton research (Russel 1927, Cushing 1951, Banse 1964) and the literature on the vertical distributions and migration of copepods is extremely large. However, most studies have been limited seasonally, or focused primarily on the adult females. 